\title{
UPAYA PENINGKATAN KEAKTIFAN DAN HASIL BELAJAR SISWA MELALUI MODEL PEMBELAJARAN STUDENT TEAMS ACHIEVEMENT DIVISION PADA MATERI MATRIKS DI SMAN 4 TEBO
}

\author{
MIRHASLI \\ SMA Negeri 4 Tebo Provinsi Jambi \\ Email : mirhasli01@gmail.com
}

\begin{abstract}
ABSTRAK
Penelitian ini bertujuan untuk meningkatkan (1) Keaktifan siswa melalui model pembelajaran Student Teams Achievement Division (STAD) pada materi Matriks di SMA Negeri 4 Tebo provinsi Jambi, (2) Hasil belajar siswa melalui model pembelajaran Student Teams Achievement Division (STAD) pada materi Matriks di SMA Negeri 4 Tebo provinsi Jambi. Metode penelitian ini adalah PTK (Penelitian Tindakan Kelas). Populasi penelitian menggunakan seluruh siswa kelas XI SMA Negeri 4 Tebo Tahun Pelajaran 2019/2020 dan subjek penelitian ini yaitu siswa kelas IPS 1 yang berjumlah 34 orang siswa. Penelitian ini merupakan penelitian tindakan kelas (PTK) yang terdiri dari 3 siklus. Setiap siklus terdiri dari tiga tahapan, yaitu (a) plan/perencanaan, (b) do/pelaksanaan, dan (c) see/refleksi. Instrumen penelitian menggunakan lembar observasi dan tes hasil belajar. Data dianalisis mengggunakan statistik deskriptif. Hasil penelitian ini yakni sebagai berikut; (1) Implementasi model pembelajaran STAD dapat meningkatkan aktifitas belajar siswa kelas XI IPS 1 SMA Negeri 4 Tebo. Hal ini dibuktikan dengan hasil keaktifan siswa pada tiap siklus yang semakin meningkat, yakni pada siklus I rerata 9,33, siklus II rerata 12,33, dan siklus II rerata 14,33; dan (2) Implementasi model pembelajaran STAD dapat meningkatkan hasil belajar matematika materi matriks siswa kelas XI IPS 1 SMA Negeri 4 Tebo dengan hasil ketuntasan belajar pada siklus I sebesar 33\%, pada siklus II sebesar 54\%, dan pada siklus III sebesar $87 \%$.
\end{abstract}

Kata Kunci: STAD, hasil belajar, matriks.

\section{PENDAHULUAN}

Belajar merupakan suatu proses kompleks pada semua orang dan berlangsung seumur hidup yang muaranya adalah adanya perubahan tingkah laku, baik berupa pengetahuan, keterampilan, dan menyangkut nilai dan sikap (Gasong, 2018). Belajar dimaknai sebagai proses perubahan perilaku sebagai hasil interaksi individu dengan lingkungannya. Perubahan perilaku terhadap hasil belajar bersifat continiu, fungsional, positif, aktif, dan terarah. Proses perubahan tingkah laku dapat terjadi dalam berbagai kondisi berdasarkan penjelasan dari para ahli pendidikan dan psikologi. Adapun pembelajaran adalah proses interaksi siswa dengan pendidik, dengan bahan pelajaran, metode penyampaian, strategi pembelajaran, dan sumber belajar dalam suatu lingkungan belajar. Kemudian, keberhasilan dalam proses belajar dan pembelajaran dapat dilihat melalui tingkat keberhasilan dalam mencapai tujuan pendidikan (Pane, dkk, 2017).

Lebih lanjut (Nasrun, 2015) mengungkapkan bahwa perubahan tingkah laku yang diperoleh baik dalam kebiasaan (habit) kecakapan (skill) maupun pengetahuan (kognitif) dari belajar merupakan hasil belajar. Menurut Juniati (2017), hasil belajar merupakan hasil yang dicapai seseorang siswa setelah melakukan usaha, sehingga muncul perubahan yang lebih baik dibandingkan sebelumnya.

Secara umum, hasil belajar dipengaruhi oleh dua faktor, yaitu faktor internal dan eksternal. Lebih lanjut Slameto (2010) memaparkan bahwa faktor internal yang mempengaruhi hasil belajar terdiri dari faktor jasmani, psikologis, dan kelelahan. Sedangkan faktor eksternal meliputi faktor yang ada di luar individu seperti faktor keluarga, sekolah, dan masyarakat (Fitriyani, 2013). Sekolah memiliki fungsi yang sangat penting dalam menentukan hasil belajar siswa. Dalam hal ini, sekolah berperan dalam proses pembelajaran yang dilakukan oleh guru di kelas dan berkaitan erat dengan model pembelajaran yang digunakan. Hal ini selaras dengan yang diungkapkan oleh Yanuarti, dkk (2016), bahwa metode atau model pembelajaran merupakan salah satu komponen yang mempengaruhi hasil belajar yang dilakukan oleh guru. 
Dapat dikatakan bahwa adanya hasil belajar siswa yang tinggi dan berkualitas, dapat dihasilkan dari proses pembelajaran yang berkualitas, untuk menghasilkan proses pembelajaran yang berkualitas seorang tenaga pendidik membutuhkan kemampuan dalam menerapkan metode pembelajaran yang sesuai dengan kebutuhan dalam kelas, ketidaksesuaian metode pembelajaran yang diterapkan dapat menurunkan kualitas proses pembelajaran itu sendiri, dengan demikian maka perbaikan dan peningkatan hasil belajar siswa di sekolah dapat dilaksanakan dengan adanya penggunaan metode pembelajaran yang tepat oleh guru (Nasution, 2018).

Hasil observasi pada proses pembelajaran matematika khususnya pada materi matriks di kelas XI IPS 1 SMA Negeri 4 Tebo menunjukkan bahwa siswa kurang memiliki antusias dalam belajar matematika khususnya materi matriks. Hal ini berdampak pada hasil belajar matematika yang diperoleh siswa, yang menunjukkan bahwa sebanyak 33\% hasil belajar matematika siswa dibawah Kriteria Ketuntasan Minimal (KKM), yaitu $\leq 75$. Hasil temuan ini menjadi dasar perlunya inovasi yang dilakukan oleh guru dalam meningkatkan hasil belajar matematika siswa. Rendahnya hasil belajar matematika siswa diduga disebabkan oleh kurangnya motivasi siswa dalam belajar, oleh karena itu guru perlu mengimplementasikan model pembelajaran lain yang dapat meningkatkan minat dan motivasi siswa dalam belajar. Dengan meningkatkan minat dan motivasi siswa dalam belajar matematika, pada akhirnya diharapkan dapat meningkatkan hasil belajar siswa. Salah satu model pembelajaran yang dapat diimplementasikan adalah model pembelajaran Student Teams Achievement Division (STAD) (Nikmah, dkk, 2016).

Model pembelajaran Student Teams Achievement Division (Selanjutnya disebut dengan STAD) merupakan pendekatan Cooperative Learning yang dapat meningkatkan aktivitas dan interaksi siswa, sehingga dapat saling memotivasi dan membantu dalam proses penguasaan materi pelajaran untuk mendapatkan hasil belajar yang maksimal (Kusuma, 2017). Pembelajaran dengan model STAD mampu menciptakan pembelajaran yang aktif, inovatif, kreatif, dan menyenangkan bagi siswa selama proses pembelajaran. Pembelajaran yang demikian akan mampu membangkitkan semangat bagi siswa untuk belajar sehingga akan berpengaruh terhadap pencapaian hasil belajar siswa yang optimal. Terdapat beberapa faktor yang menjadikan model ini mampu menciptakan suasana pembelajaran yang menyenangkan bagi siswa. Faktor tersebut adalah karakter STAD sebagai model pembelajaran yang menuntut kerjasama, pembelajaran berpusat pada siswa (Student Centered), dan adanya penghargaan bagi tim terbaik.

Pemilihan model pembelajaran STAD disebabkan oleh beberapa alasan, yaitu (1) dengan model pembelajaran STAD, interaksi diantara siswa terbentuk, sehingga diharapkan dapat meningkatkan minat siswa dalam belajar, dan (2) model ini dapat memunculkan adanya perspektif motivasi, perspektif social, serta perspektif perkembangan kognitif (Muharom, 2014). Model STAD sangat menekankan pada kerjasama dalam kelompok belajar. Hal ini akan menuntut siswa untuk saling membantu, memberi motivasi, dan saling percaya satu sama lain. Pembelajaran yang menekankan pada kerjasama akan memberi kesempatan kepada siswa untuk belajar bekerjasama, berbagi pendapat, pengetahuan, pengalaman, mendengarkan pendapat orang lain, saling memotivasi dan aktif dalam kegiatan pembelajaran. Bentuk kerjasama dalam model STAD diwujudkan dalam pembentukan tim belajar siswa. Tim terdiri dari empat atau lima siswa yang mewakili seluruh bagian dari kelas dalam kinerja akademik, jenis kelamin, ras dan etnisitas. Fungsi dibentuknya kelompok adalah agar siswa anggota kelompok dapat bekerjasama menyelesaikan tugas yang diberikan dan saling membantu untuk menguasai materi dengan baik. Hal ini karena sesama siswa memiliki kesamaan bahasa, tingkat perkembangan intelektual dan pengalaman kedekatan sehingga membuat siswa lebih mudah memahami materi pelajaran (Saragih, dkk, 2013).

Sintaks dalam model pembelajaran STAD menjadikan siswa sebagai pusat dalam kegiatan pembelajaran (Student Centered). Pembelajaran semacam ini akan meningkatkan intensitas keterlibatan siswa secara aktif di dalam proses pembelajaran. Proses aktif dalam 
bertanya dan berargumen ini memberikan kesempatan siswa untuk mengekspresikan dirinya dan menumbuhkan pemikiran kritis pada siswa. Siswa sebagai pusat dalam proses pembelajaran memungkinkan siswa untuk menghasilkan solusi yang baru atas suatu permasalahan yang diberikan oleh guru. Ekspresi diri, pemikiran kritis dan penemuan yang dilakukan oleh siswa tentunya akan menumbuhkan kreativitas dalam diri siswa. Hal ini akan berpengaruh positif terhadap suasana pembelajaran yang menyenangkan karena tidak ada pemberian penekanan pada siswa (Azni, dkk, 2015).

Berdasarkan dari uraian diatas model STAD merupakan pilihan yang tepat dalam pembelajaran karena model ini dapat menciptakan pembelajaran yang aktif, inovatif, kreatif, dan menyenangkan bagi siswa. Hal ini akan membuat kegiatan pembelajaran di kelas menjadikan siswa tidak merasa bosan dan jenuh dalam mengikuti kegiatan pembelajaran. Dengan karakter STAD yang menekankan pada kerjasama dalam kelompok, pembelajaran berpusat pada siswa (Student Centered), dan adanya penghargaan bagi tim terbaik akan membuat siswa lebih meningkatkan aktivitas dan semangat siswa, khusunya aktivitas dalam berkomunikasi dengan sesama teman anggota kelompok belajarnya. Kemudian dengan adanya penghargaan kelompok dapat meningkatkan motivasi belajar siswa (Lubis, 2012). Oleh karena itu, dengan model pembelajaran STAD dapat meningkatkan partisipasi aktif dalam kegiatan pembelajaran dan motivasi siswa yang tentunya partisipasi aktif tersebut berpengaruh positif terhadap hasil belajar siswa.

\section{METODE PENELITIAN}

Penelitian ini merupakan penelitian tindakan kelas (PTK). Penelitian tindakan kelas merupakan penelitian deskriptif karena menggambarkan suatu teknik pembelajaran. Kegiatan penelitian ini terdiri dari 3 siklus, dan masing-masing siklus mengadopsi langkah-langkah penelitian PTK yang dikembangkan oleh Slameto (2015) sebagai berikut: (1) Plan/Tahap Perencanaan, (2) Do/Melakukan Tindakan, dan (3) See/Melakukan Refleksi. Berikut dijabarkan masing-masing tahapan pelaksanaan PTK.

Penelitian ini dilakukan pada semester ganjil Tahun Pelajaran 2019/2020 dengan subjek penelitian siswa kelas XI IPS 1 SMA Negeri 4 Tebo, Kabupaten Tebo Provinsi Jambi yang berjumlah 34 orang. Ruang lingkup penelitian ini dibatasi pada mata pelajaran matematika dan pokok bahasan Matriks. Keberhasilan penelitian dilihat dari dua aspek, yaitu (1) peningkatan kualitas proses pembelajaran yang dilihat dari tingkat keaktifan siswa yang terdiri dari 4 indikator, yaitu (a) kemampuan bertanya, (b) kemampuan mengeluarkan pendapat, (c) kemampuan berhitung, (d) inisiatif dengan ide baru, dan (e) penuh perhatian; dan (2) peningkatan hasil belajar yang dilihat dari nilai tes siswa mulai dari siklus I sampai siklus III.

Instrumen yang digunakan dalam penelitian ini dibagi dua, yaitu (1) lembar observasi keterlaksanaan RPP. Lembar observasi keterlaksanan RPP digunakan pada tiap siklus untuk melihat efektifitas proses pembelajaran sesuai dengan RPP yang telah disusun pada tahap plan; (2) tes hasil belajar. Tes hasil belajar dilaksanakan pada tiap akhir siklus dan digunakan untuk mengukur hasil belajar matematika siswa pada masing-masing siklus.

Pengumpulan data dilakukan untuk melihat dua aspek, yaitu (1) keaktifan siswa, dan (2) hasil belajar siswa. Data aktivitas belajar siswa diperoleh dari hasil pengamatan selama kegiatan pembelajaran berlangsung, sedangkan data hasil belajar siswa diperoleh dari tes akhir yang diadakan pada tiap akhir siklus. Teknik analisis data dalam penelitian ini dilakukan melalui analisis deskriptif kualitatif untuk menjabarkan hasil atau temuan penelitian pada masing-masing tahapan penelitian untuk tiap siklus, dan analisis deskriptif kuantitatif untuk menjabarkan hasil tes siswa berupa persentase ketuntasan belajar, nilai terendah, nilai tertinggi, dan nilai rata-rata.

\section{HASIL DAN PEMBAHASAN}

Kegiatan penelitian terdiri dari tiga siklus, yaitu siklus I, II, dan III. Hasil penelitian ini menjabarkan hasil plan, do, dan see masing-masing siklus dengan menjabarkan pencapaian 
peningkatan proses yang dilihat dari keaktifan siswa dan peningkatan hasil belajar matematika siswa. Berikut dijabarkan hasil penelitian masingmasing siklus.

\section{Siklus I}

Kegiatan penelitian pada siklus I mengikuti rangkaian kegiatan yang dimulai dari plan, do dan see. Kegiatan siklus I dilaksanakan tanggal 1 September 2019. Kegiatan plan diisi dengan (a) penyusunan RPP bersama guru dan obsrver, dan (b) menyusun lembar pengamatan kegiatan proses belajar.

Kegiatan $d o$ atau tahap pelaksanaan dilakukan di kelas dengan mengimplementasikan model pembelajaran STAD. Pada saat proses pembelajaran berlangsung, observer mengamati dan mencatat aktivitas siswa yang meliputi (a) kemampuan bertanya, (b) kemampuan mengeluarkan pendapat, (c) kemampuan berhitung, (d) inisiatif dengan ide baru, dan (e) penuh perhatian. Berikut ditampilkan data keaktifan siswa yang disajikan pada Tabel 1.

Tabel 1. Rekapitulasi Hasil Pengamatan Keaktifan Siswa pada Siklus I

\begin{tabular}{|c|c|c|c|c|c|}
\hline No & Uraian & $\begin{array}{c}\text { Obs } \\
\text { I }\end{array}$ & $\begin{array}{c}\text { Obs } \\
\text { II }\end{array}$ & $\begin{array}{l}\text { Obs } \\
\text { III }\end{array}$ & Rerata \\
\hline 1 & $\begin{array}{l}\text { Kemampuan } \\
\text { bertanya }\end{array}$ & 1 & 1 & 1 & 1,00 \\
\hline 2 & $\begin{array}{l}\text { Kemampuan mengeluarkan } \\
\text { pendapat }\end{array}$ & 2 & 2 & 2 & 2,00 \\
\hline 3 & $\begin{array}{l}\text { Kemampuan } \\
\text { berhitung }\end{array}$ & 2 & 2 & 2 & 2,00 \\
\hline 4 & $\begin{array}{l}\text { Inisiatif } \\
\text { dengan ide } \\
\text { baru }\end{array}$ & 2 & 2 & 2 & 2,00 \\
\hline 5 & Penuh perhatian & 2 & 2 & 3 & $\begin{array}{l}2,33 \\
9,33\end{array}$ \\
\hline
\end{tabular}

Pada akhir kegiatan proses pembelajaran dilakukan tes untuk mengetahui hasil belajar matematika siswa. Tes yang diberikan berupa soal pilihan ganda dan essay yang masing-masing berjumlah 10 soal dan 5 soal. Berikut ditampilkan data hasil belajar siswa yang disajikan pada Tabel 2.

Tabel 2. Rekapitulasi Hasil Belajar Siswa pada Siklus I

\begin{tabular}{lll} 
No & Hasil Tes & Pencapaian \\
\hline 1 & Nilai rata-rata & 63,7 \\
2 & Nilai tertinggi & 88,0 \\
3 & Nilai terendah & 25,0 \\
4 & Ketuntasan belajar & $33 \%$ \\
\hline
\end{tabular}

Pada akhir kegiatan siklus I dilakukan tahapan see atau refleksi bersama guru dengan observer untuk mengetahui kekurangan atau kelebihan proses pembelajaran, maupun hal-hal posistif maupun negatif terkait dengan aktivitas siswa ketika mengikuti pembelajaran. Hasil refleksi siklus I menemukan hal-hal sebagai berikut: (a) sebagai besar siswa terlihat antusias mengikuti kegiatan pembelajaran menggunakan model STAD, (b) kualitas jawaban sebagian siswa masih kurang baik meskipun antusias mereka cukup tinggi, (c) pada siswa yang memiliki latar belakang prestasi yang kurang baik (slow learner) tampak adanya rasa ketakutan untuk ditanya atau bertanya, (d) guru perlu melakukan apersepsi di awal pembelajaran untuk menggali 
kemampuan awal siswa, dan (e) guru perlu memberikan reward dan punishment untuk meningkatkan motivasi siswa dalam belajar.

\section{Siklus II}

Kegiatan siklus II dilakukan untuk perbaikan kekurangan-kekurangan pelaksanaan pembelajaran pada siklus I. Kegiatan siklus II dilakukan melalui tiga tahapan, yaitu plan, do, dan see sebagaimana dilakukan pada siklus I. Pada tahapan plan dilakukan penyusunan perangkat pembelajaran meliputi RPP yang telah mengalami perbaikan berdasarkan temuantemuan pada siklus I. Beberapa kondisi yang perlu mendapat perbaikan pada RPP meliputi: (a) penyajian pertanyaan sebaiknya menggunakan bahasa yang lebih mudah dipahami oleh siswa, (b) perlunya pemberian reward atau penguatan untuk meningkatkan motivasi belajar siswa, dan (c) guru perlu menyampaikan materi pelajaran yang akan dipelajari pada pertemuan berikutnya, supaya siswa lebih siap dalam belajar.

Kegiatan do dilakukan melalui implementasi model pembelajaran STAD dalam proses pembelajaran di kelas. Kegiatan do mengacu pada RPP yang telah disusun pada saat tahap perencanaan. Pada saat proses pembelajaran berlangsung, masing-masing observer melakukan pengamatan terhadap seluruh aktivitas siswa di kelas. Berikut dijabarkan data aktivitas siswa selama kegiatan pembelajaran pada siklus II berlangsung yang disajikan pada Tabel 3.

Tabel 3. Rekapitulasi Hasil Pengamatan Keaktifan Siswa pada Siklus II

\begin{tabular}{lccccc}
\hline No & Uraian & Obs & Obs & Obs & Rerata \\
& Kemampuan bertanya & I & II & III & \\
1 & 1 & 2 & 2 & 1,67 \\
2 & Kemampuan mengeluarkan & 3 & 2 & 2 & 2,33 \\
pendapat & & & & \\
3 & Kemampuan berhitung & 3 & 2 & 2 & 2,33 \\
4 & Inisiatif dengan ide baru & 4 & 3 & 3 & 3,33 \\
5 & Penuh perhatian & 2 & 3 & 3 & 2,67 \\
& & & & & 12,33 \\
\hline
\end{tabular}

Pada akhir proses pembelajaran dilakukan tes formatif untuk melihat peningkatan hasil belajar siswa. Berikut ditampilkan data hasil tes formatif untuk melihat peningkatan hasil belajar siswa yang disajika pada Tabel 4.

\begin{tabular}{|clc} 
Tabel 4. & Rekapitulasi Hasil Belajar Siswa pada Siklus II \\
No & Hasil Tes & Pencapaian \\
\hline 1 & Nilai rata-rata & 71,3 \\
2 & Nilai tertinggi & 90,0 \\
3 & Nilai terendah & 30,0 \\
4 & Ketuntasan belajar & $54 \%$ \\
\hline
\end{tabular}

Setelah melakukan serangkaian kegiatan plan dan $d o$, tahap terakhir kegiatan penelitian pada siklus II diakhiri dengan kegiatan refleksi (see). Berdasarkan hasil refleksi ditemukan beberapa hal sebagai berikut: (a) antusiasme siswa dalam belajar mengalami peningkatan dibandingkan pertemuan sebelumnya, (b) pertanyaanpertanyaan yang diberikan oleh guru tampak dipahami oleh siswa yang ditunjukkan dengan kemampuan menanggapi atau memberikan jawaban yang sesuai dengan pertanyaan tersebut, (c) pemberian reward atau penguatan kepada siswa tampak sudah diberikan oleh guru, (d) belum adanya penjelasan penilaian proses kepada siswa, walaupun kegiatan tersebut sudah dilakukan oleh guru, dan (e) waktu pelaksanaan kegiatan belajar belum sesuai dengan perencanaan. 


\section{Siklus III}

Berdasarkan temuan pada kegiatan refleksi siklus II, maka peneliti melakukan kegiatan penelitian siklus III untuk memperbaiki kekurangan pada siklus II. Tahapan penelitian pada siklus III dilakukan melalui kegiatan plan, do, dan see. Rencana pelaksanaan pembelajaran (RPP) yang disusun pada siklus III merupakan RPP penyempurnaan berdasarkan masukan dan saran perbaikan pada siklus II. Pada pertemuan sebelumnya, ditemukan bahwa waktu pelaksanaan kegiatan pembelajaran yang dilakukan oleh guru belum sesuai dengan alokasi waktu yang dituangkan dalam RPP. Oleh karena itu, dalam rangka implementasi model pembelajaran STAD di kelas beberapa sintak pembelajaran yang ditulis dalam RPP benar-benar diterapkan sesuai dengan alokasi yang ditetapkan. Hal ini dilakukan untuk membuat proses pembelajaran menjadi lebih efektif dan efisien. Dengan adanya perbaikan-perbaikan pada perencanaan dan implementasi pembelajaran, menunjukkan adanya efektifitas pembelajaran, hal ini berdampak tehadap interaksi dan motivasi belajar siswa.

Hal ini dibuktikan dengan semakin tingginya keaktifan siswa dalam belajar dan hasil belajar siswa yang semakin meningkat dari siklus sebelumnya. Berikut ditampilkan data aktivitas hasil belajar siswa pada siklus III yang ditampilkan pada Tabel 5 dan 6 .

Tabel 5. Rekapitulasi Hasil Pengamatan Keaktifan Siswa pada Siklus III

\begin{tabular}{|c|c|c|c|c|c|}
\hline No & Uraian & $\begin{array}{c}\text { Obs } \\
\text { I }\end{array}$ & $\begin{array}{c}\text { Obs } \\
\text { II }\end{array}$ & $\begin{array}{l}\text { Obs } \\
\text { III }\end{array}$ & Rerata \\
\hline 1 & $\begin{array}{l}\text { Kemampuan } \\
\text { bertanya }\end{array}$ & 2 & 2 & 3 & 2,33 \\
\hline 2 & Kemampuan mengeluarkan pendapat & 3 & 2 & 3 & 2,67 \\
\hline 3 & $\begin{array}{l}\text { Kemampuan } \\
\text { berhitung }\end{array}$ & 3 & 2 & 3 & 2,67 \\
\hline 4 & Inisiatif dengan & 4 & 3 & 3 & 3,33 \\
\hline 5 & Penuh perhatian & 4 & 3 & 3 & $\begin{array}{l}3,33 \\
14,33\end{array}$ \\
\hline
\end{tabular}

Tabel 6. Rekapitulasi Hasil Belajar Siswa pada Siklus III

\begin{tabular}{lll} 
No & Hasil Tes & Pencapaian \\
\hline 1 & Nilai rata-rata & 82,3 \\
2 & Nilai tertinggi & 90,0 \\
3 & Nilai terendah & 48,0 \\
4 & Ketuntasan belajar & $87 \%$ \\
\hline
\end{tabular}

Berdasarkan hasil refleksi (see) ditemukan bahwa kegiatan pembelajaran yang dilakukan oleh guru dengan mengimplementasikan model pembelajaran STAD di kelas mengalami perbaikan dari siklus I sampai dengan siklus III. Proses pembelajaran kelihatan efektif karena seluruh sintak pembelajaran yang tertuang dalam RPP telah dilaksanakan dengan baik oleh guru. Oleh karena itu, kegiatan pembelajaran sudah dianggap optimal sehingga kegiatan penelitian tidak perlu dilanjutkan lagi dengan siklus berikutnya.

\section{Pembahasan}

Berdasarkan hasil penelitian diketahui bahwa terjadi peningkatan aktivitas siswa dari siklus I sampai dengan III yang dilihat dari 5 indikator. Data pada Tabel 1, 3, dan 5 menunjukkan bahwa aktivitas siswa pada siklus I masih rendah, kemudian mengalami peningkatan pada siklus II dan aktivitas siswa dalam pembelajaran semakin tinggi pada siklus III. Rendahnya aktivitas siswa pada siklus I diduga disebabkan karena guru dan siswa masih beradaptasi dengan model pembelajaran baru yang diimplementasikan, yaitu model pembelajaran STAD. Hal ini dibuktikan dengan hasil pengamatan oleh observer yang 
menunjukkan bahwa beberapa sintak pembelajaran belum dilaksanakan sepenuhnya oleh guru, seperti memberikan apersepsi di awal pembelajaran dan memberikan penguatan kepada siswa ketika proses pembelajaran.

Beberapa kekurangan dalam proses pembelajaran yang dilaksanakan pada siklus I disempurnakan pada siklus II. Dampaknya, aktivitas siswa pada siklus II menunjukkan adanya peningkatan dari siklus sebelumnya (Tabel 3). Hal ini menunjukkan bahwa proses pembelajaran yang dilaksanakan guru di kelas cenderung lebih efektif dibandingkan pertemuan sebelumnya, sehingga dapat memberikan pengaruh terhadap minat dan motivasi siswa dalam belajar yang tercermin dalam jumlah siswa yang bertanya, mengeluarkan pendapat, memiliki kemampuan berhitung, inisiatif dengan ide baru, dan penuh perhatian semakin meningkat dari siklus I. Namun demikian, berdasarkan hasil refleksi siklus II masih terdapat kelemahan dalam siklus II yang perlu mendapat perhatian dalam penyempurnaan pembelajaran pada pertemuan berikutnya, yaitu efisiensi penggunaan waktu pembelajaran.

Berdasarkan data aktivitas siswa pada Tabel 5 menunjukkan bahwa terjadi peningkatan aktivitas siswa yang cukup signifikan dibandingkan pada siklus I dan II. Tingginya aktivitas siswa pada siklus III diduga disebabkan oleh penyempurnaan rencana dan kegiatan pembelajaran yang dilakukan oleh guru di kelas berdasarkan refleksi kekurangan pada siklus sebelumnya. Dengan penyempurnaan perencanaan dan pelaksanakan kegiatan pembelajaran yang dilakukan oleh guru, kegiatan pembelajaran semakin efektif dan efisien sehingga sintak pembelajaran STAD dapat dilaksanakan dengan baik. Salah satu keunggulan model pembelajaran STAD adalah dapat meningkatkan aktivitas dan interaksi siswa.

Data hasil belajar siswa menunjukkan adanya peningkatan yang cukup signifikan dari siklus I sampai dengan siklus III. Rata-rata nilai pada siklus I sampai dengan III berturut-turut 63,7; 71,3; dan 82,3 (Tabel 2, 4, dan 6). Hasil belajar yang terus meningkat diduga karena semakin baiknya proses pembelajaran yang dilakukan oleh guru di kelas, sehingga sintak pembelajaran STAD dapat dilaksanakan dengan baik. Dilihat dari segi perkembangan kognitif, model pembelajaran STAD dapat meningkatkan hasil belajar siswa. Hal ini dibuktikan dengan hasil penelitian yang lain seperti Firdaus (2016) yang menguji pengaruh model pembelajaran STAD terhadap hasil belajar matematika pada materi operasi hitung bentuk aljabar di SMP Negeri 1 Kendawan menunjukkan bahwa model pembelajaran STAD dapat meningkatkan hasil belajar matematika siswa. Hal serupa juga pernah dilakukan oleh Anjasari et al (2015) yang menunjukkan bahwa implementasi model pembelajaran STAD dapat meningkaktan hasil belajar matematika siswa kelas VIII SMP Negeri 2 Wakorumba Utara, Kabupaten Muna.

\section{KESIMPULAN}

Berdasarkan hasil penelitian yang didapatkan, maka Simpulan yang diperoleh dari hasil penelitian ini yakni sebagai berikut; (1) Implementasi model pembelajaran STAD dapat meningkatkan aktifitas belajar siswa kelas XI IPS 1 SMA Negeri 4 Tebo. Hal ini dibuktikan dengan hasil keaktifan siswa pada tiap siklus yang semakin meningkat, yakni pada siklus I rerata 9,33, siklus II rerata 12,33, dan siklus II rerata 14,33; dan (2) Implementasi model pembelajaran STAD dapat meningkatkan hasil belajar matematika materi matriks siswa kelas XI IPS 1 SMA Negeri 4 Tebo dengan hasil ketuntasan belajar pada siklus I sebesar 33\%, pada siklus II sebesar 54\%, dan pada siklus III sebesar $87 \%$.

\section{DAFTAR PUSTAKA}

Anjasari, E \& Ibrahim, M. 2015. Pengaruh Model Pembelajaran Kooperatif Tipe Student Teams Achievement Division Terhadap Hasil Belajar Matematika Siswa Kelas Viii Smp Negeri 2 Wakorumba Utara Kabupaten Muna, Jurnal Penelitian Pendidikan Matematika, Vol 3 (3): 15-26.

Azni, T. N., \& Jailani, J. (2015). Pengembangan perangkat pembelajaran trigonometri berbasis strategi pembelajaran inkuiri melalui model pembelajaran kooperatif tipe STAD. Jurnal Riset Pendidikan Matematika, 2(2), 284-295. 
Firdaus, M. 2016. Pengaruh Model Pembelajaran Kooperatif Tipe Student Teams Achievement Division (STAD), Jurnal Pendidikan Informatika dan Sains, Vol 5 (1): 96104.

Fitriani, F. (2013). Pengaruh Penggunaan Metode Pembelajaran dan Fasilitas Belajar terhadap Prestasi Belajar pada Mata Pelajaran Ekonomi. Oikonomia: Jurnal Pendidikan Ekonomi, 2(4), 27856.

Gasong, D. (2018). Belajar dan pembelajaran. Deepublish.

Kusuma, A. P. (2017). Implementasi Model Pembelajaran Student Teams Achievement Division dan Team Assisted Individualization ditinjau dari Kemampuan Spasial Siswa. Al-Jabar: Jurnal Pendidikan Matematika, 8(2), 135-144.

Lubis, A. (2012). Pengaruh Model Pembelajaran Kooperatif Tipe STAD Terhadap Hasil Belajar Fisika Siswa Pada Materi Pokok Gerak Lurus di Kelas X SMA Swasta UISU Medan. Jurnal Pendidikan Fisika, 1(1), 27-32.

Muharom, T. (2014). Pengaruh pembelajaran dengan model kooperatif tipe Student Teams Achievement Division (STAD) terhadap kemampuan penalaran dan komunikasi matematik siswa di SMK Negeri Manonjaya Kabupaten Tasikmalaya. Jurnal Pendidikan dan Keguruan, 1(1), 209691.

Nasrun, A. R., \& Nasrun, A. R. (2015). Psikologi Belajar. Al-Fikrah: Jurnal Kependidikan Islam IAIN Sulthan Thaha Saifuddin, 6, 56878.

Nasution, M. K. (2018). Penggunaan metode pembelajaran dalam peningkatan hasil belajar siswa. Studia Didaktika, 11(01), 9-16.

Nikmah, E. H., Fatchan, A., \& Wirahayu, Y. A. (2016). Model pembelajaran student teams achievement divisions (stad), keaktifan dan hasil belajar siswa. Jurnal Pendidikan Geografi, 3(3), 1-17.

Pane, A., \& Dasopang, M. D. (2017). Belajar dan pembelajaran. Fitrah: Jurnal Kajian IlmuIlmu Keislaman, 3(2), 333-352.

Saragih, S., \& Rahmiyana, R. (2013). Peningkatan kemampuan komunikasi matematis siswa SMA/MA di kecamatan simpang ulim melalui model pembelajaran kooperatif tipe STAD. Jurnal Pendidikan dan Kebudayaan, 19(2), 174-188.

Slameto, S. (2015). Implementasi Penelitian Tindakan Kelas. Scholaria: Jurnal Pendidikan Dan Kebudayaan, 5(3), 47-58.

Yanuarti, A., \& Sobandi, A. (2016). Upaya meningkatkan hasil belajar siswa melalui penerapan model pembelajaran quantum teaching. Jurnal Pendidikan Manajemen Perkantoran (JPManper), 1(1), 11-18. 